\title{
Maintenance of the Therapeutic Effect of Two High-Dosage Antimuscarinics in the Management of Overactive Bladder in Elderly Women
}

\author{
Kirill Kosilov, Sergey Loparev ${ }^{1}$, Marina Ivanovskaya ${ }^{2}$, Liliya Kosilova ${ }^{3}$ \\ Far Eastern Federal University, Vladivostok; \\ ${ }^{1}$ Department of Urology, City Polyclinic No. 3, Vladivostok; \\ ${ }^{2}$ Far Eastern State University of Fishing, Vladivostok; \\ ${ }^{3}$ Medical Alliance No. 2, Vladivostok, Russia
}

Purpose: To improve the long-term efficiency of the pharmacologic management of overactive bladder (OAB) in elderly women.

Methods: The study comprised 229 women (mean age, 66.3 years; range, 65-77 years) with urodynamically and clinically confirmed OAB. All patients received the most effective treatment regimen based on the data obtained in the initial part of the study (trospium $60 \mathrm{mg} / \mathrm{day}$ + solifenacin $40 \mathrm{mg} / \mathrm{day}$, for 6 weeks), and positive results similar to those in the first phase were obtained. They were then divided into four groups, based on the maintenance therapy: group A (59 women), trospium (60 mg/ day) + solifenacin (40 mg/day) for 1 month; group B (51 women), electrical stimulation of the detrusor muscle for 1 month; group C ( 63 women), laser puncture for 1 month; group D (56 women), placebo. Maintenance therapy was administered 2.5 months after completion of primary treatment. The patients' condition was monitored through the OAB questionnaire for 1 year and by urodynamic examination at months 6 and 7 from the start of the study.

Results: In group A, the clinical and urodynamic results achieved after the initial + main treatment phase (two high-dosage antimuscarinics of different generations, trospium and solifenacin, for a total of 2.5 months) were maintained for at least 7 months. Electrical stimulation of the urinary bladder as a method of maintenance therapy proved to be less effective. In groups C and D, deterioration in results was observed at 6-8 months, which led us to conclude that laser puncture was an inefficient method of maintenance therapy in elderly women with $\mathrm{OAB}$.

Conclusions: Maintenance treatment of $\mathrm{OAB}$ in elderly women with a combination of high-dosage antimuscarinics is an effective method for reducing the risk of recurrence of the disease.

Keywords: Overactive urinary bladder; Older women; Muscarinic antagonists; Long-term results

\section{INTRODUCTION}

The prevalence of overactive bladder $(\mathrm{OAB})$ in women significantly increases after 45-50 years of age. One-third of women aged $>65$ years have disorderly lower urinary tract functions; furthermore, in approximately two-thirds of these women, $\mathrm{OAB}$ is accompanied by incontinence events (IE), resulting in a considerable reduction in the quality of life [1-3]. Development of
$\mathrm{OAB}$ in elderly women is explained by a decrease in the functional consistency of the intramural ganglia, occurrence of "afferent noise" in the detrusor, a decrease in the number of functionally effective $M_{2}$ receptors and (to lesser degree) $M_{1}$ and $M_{4}$ receptors in the bladder, weakening of the pelvic floor muscles, and other processes. However, some aspects of the pathophysiological mechanisms involved in this process remain controversial $[4,5]$.
Corresponding author: Kirill Kosilov

Far Eastern Federal University, Ocean Avenue 27, Office 324 c, Vladivostok, Russia

Tel: +7-914-717-3915 / Fax: +7-423-231-2169 / E-mail: oton2000@mail.ru Submitted: August 17, 2013 / Accepted after revision: December 3, 2013
This is an Open Access article distributed under the terms of the Creative Commons Attribution Non-Commercial License (http://creativecommons.org/licenses/by-nc/3.0/) which permits unrestricted non-commercial use, distribution, and reproduction in any medium, provided the original work is properly cited. 
Management of $\mathrm{OAB}$ with antimuscarinics is well documented. Among the anticholinergic drugs, oxybutynin, solifenacin, tolterodine, and trospium have been proven effective and clinically recommended. However, these drugs do not provide satisfactory relief in some patients owing to inadequate therapeutic efficiency [6-8]. In previous studies, we noted an improvement in the therapeutic effect of two high-dosage antimuscarinics (trospium and solifenacin) in elderly patients without a statistically significant increase in side effects [9]. Similar results were obtained by other researchers [10,11].

However, issues concerning the long-term maintenance of stable results of the pharmaceutical treatment of $\mathrm{OAB}$ in elderly women require further research [12-14].

In this study, our goal was to compare the effectiveness of different maintenance therapies following satisfactory initial results of $\mathrm{OAB}$ treatment in elderly women with double dosages of trospium and solifenacin.

\section{MATERIALS AND METHODS}

This study investigated the efficiency of OAB treatment in elderly women administered combined high-dosage antimuscarinics. During the initial phase of the study, we established that the use of high-dosage trospium and solifenacin $(60 \mathrm{mg} /$ day and $30-40 \mathrm{mg} /$ day, respectively) in elderly women resulted in stable clinical and urodynamic effects and prevented aggravation of the patients' condition with few side-effects. A follow-up study, conducted 4 months after treatment completion, demonstrated insignificant deterioration in the results and a significant aggravation of the patients' condition after 8 months according to the most instrumental and clinical parameters [9].

The next step of the study was a search for an optimal maintenance regimen that would maintain the initial effect and decrease the risk of $\mathrm{OAB}$ recurrence. The results have been reported in this study. We randomly selected 229 women (mean age, 66.3 years; range, $67-77$ years) with urodynamically and clinically confirmed OAB. All patients received the most effective treatment regimen based on the data obtained from our initial study (trospium $60 \mathrm{mg} /$ day + solifenacin $40 \mathrm{mg} /$ day for 1 month) [9], with results similar to the first phase, then they were divided into four groups based on the type of maintenance therapy: group A (59 women), trospium (60 mg/day) + solifenacin (40 mg/day) for 1 month; group B (51 women), electrical stimulation of the detrusor with an active electrode $\left(50-70 \mathrm{~cm}^{2}\right)$ above the pubis and an indifferent electrode $\left(150 \mathrm{~cm}^{2}\right)$ to the lumbosacral area (using Bernard's current: frequency, $20 \mathrm{~Hz}$; depth of modulation, 50-75\%; strength, 20-40 mA; exposure time, 15 minutes; cycle of 15 procedures performed every second day) [15-19]; group C (63 women), laser puncture using a helium-neon laser $(632.8 \mathrm{~nm})$ applied to the projection of the acupuncture points RP 6, RP 9, VC 2 for 1-1.5 minutes, to each point daily (output power of the light guide, $2 \mathrm{~mW} ; 25$ procedures) [20-23]; group D (56 women), placebo. The cycle of maintenance therapy was conducted 2.5 months after completion of primary treatment.

The patients' condition was monitored through OAB questionnaires for 1 year $[24,25]$ and urodynamic examination (before enrollment and at 6 and 12 months after primary treatment). The urodynamic state of the lower urinary tract was evaluated in accordance with the International Continence Society guidelines [26-28]. A UDS “Relief-01” (DALPRIBOR, Vladivostok, Russia) with double-catheter microtip (UROBAR, CH 9; Raumedic AG, Helmbrechts, Germany) was used for the standard urodynamic procedure. The following data were recorded and analyzed: maximal bladder capacity, volume at first unstable contraction (reflex volume) of the bladder, maximum detrusor pressure, and detrusor compliance. Parameters of treatment effectiveness were determined as follows: intravesical pressure, $\geq 40 \mathrm{~cm} \mathrm{H} \mathrm{H}_{2} \mathrm{O}$; minimal bladder capacity, $300 \mathrm{~mL}$; detrusor compliance, $>25 \mathrm{~mL} / \mathrm{cm} \mathrm{H}_{2} \mathrm{O}$; negative trend of episodes incontinence, $\geq 2$ units/day [10].

Initial data were collected using the application program Excel of the standard package Microsoft-XP (Microsoft-Rus; Vladivostok, Russia) and analyzed with the statistical analysis program SAS 8.0.2 (SAS Institute Inc., Cary, NC, USA). Wilcoxon and Kruskal-Wallis tests were used to compare results in each treatment group before and after supplement of another drug. A one-way analysis of variance using Tukey significance test was used to compare the effects in the three groups. Standard deviation values of $\mathrm{P}<0.05$ were considered statistically significant.

The study was performed in accordance with the guidelines for Good Clinical Practice and the Declaration of Helsinki. Prior written informed consent was obtained from each patient [29-32]. Fig. 1 shows the examination and treatment of patients.

\section{RESULTS}

Tables 1 and 2, and Fig. 2 show that the best results were observed in group A. The mean number of IE decreased within 2 


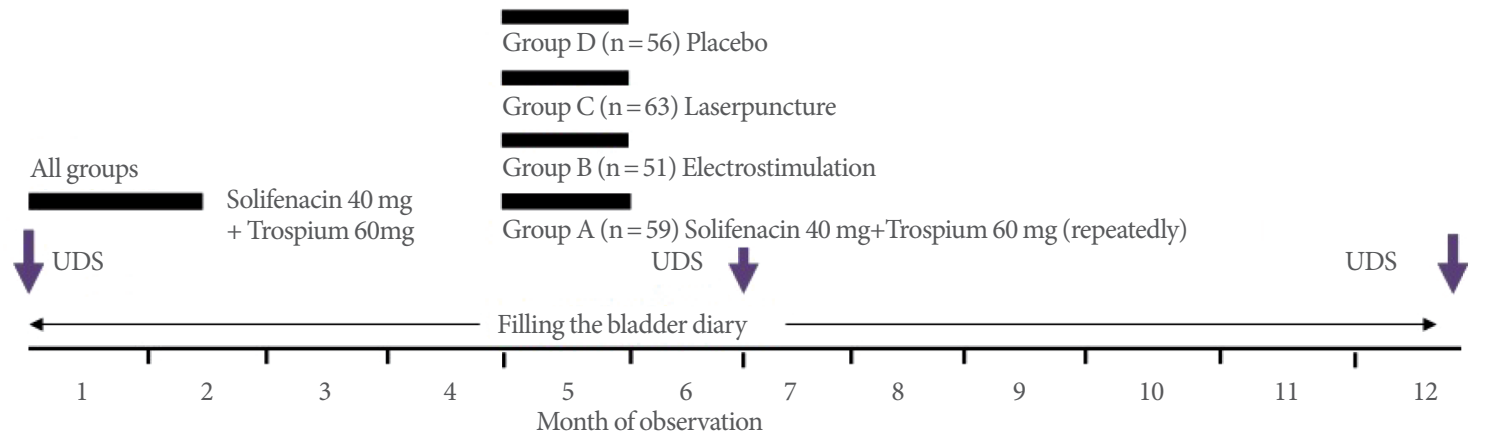

Fig. 1. Algorithm of examination and treatment of elderly patients with overactive bladder $(n=229)$. The arrow shows the urodynamic survey (UDS).

Table 1. Urodynamic examination result $(\mathrm{n}=229)$

\begin{tabular}{|c|c|c|c|c|c|c|c|c|c|}
\hline \multirow{2}{*}{ Group } & \multicolumn{3}{|c|}{ Reflex volume (mL) } & \multicolumn{3}{|c|}{ Bladder capacity $(\mathrm{mL})$} & \multicolumn{3}{|c|}{ Detrusor compliance $\left(\mathrm{mL} / \mathrm{cm} \mathrm{H}_{2} \mathrm{O}\right)$} \\
\hline & Before treat ${ }^{\mathrm{a})}$ & After treat ${ }^{\mathrm{b})}$ & After treat ${ }^{c}$ & Before treat $\mathrm{t}^{\mathrm{a})}$ & After treat ${ }^{\text {b) }}$ & After treat ${ }^{c}$ & Before treat ${ }^{a)}$ & After treat ${ }^{\mathrm{b})}$ & After treat ${ }^{c)}$ \\
\hline$A(n=59)$ & $145.8(37.6)$ & $289.3(63.7)^{\star *}$ & $257.5(28.9)^{\star *}$ & $180.1(31.0)$ & $313.7(47.1)^{\star \star}$ & $279.9(33.8)^{*}$ & $20.2(2.5)$ & $32.8(6.0)^{*}$ & $28.8(4.7)^{\star}$ \\
\hline $\mathrm{B}(\mathrm{n}=51)$ & $136.1(37.7)$ & $297.0(45.3)^{* *}$ & $210.9(28.7)^{\star}$ & $171.1(45.0)$ & $334.8(38.3)^{\star *}$ & $251.9(42.9)$ & $17.5(3.3)$ & $35.4(9.3)^{\star}$ & $30.9(4.9)^{*}$ \\
\hline$C(n=63)$ & $131.2(54.5)$ & $254.5(49.1)^{\star}$ & $199.3(49.4)$ & $168.3(55.8)$ & $286.0(36.6)^{*}$ & $178.9(29.0)$ & $21.3(6.6)$ & $38.9(7.8)^{\star}$ & $29.8(6.3)$ \\
\hline $\mathrm{D}(\mathrm{n}=56)$ & $167.6(32.1)$ & $279.7(54.8)^{\star}$ & $192.9(28.9)$ & $191.5(58.6)$ & $311.5(51.7)^{\star}$ & $206.3(26.9)$ & $21.9(5.4)$ & $31.0(7.9)$ & $23.9(5.4)$ \\
\hline
\end{tabular}

Values are presented as mean ( \pm standard deviation).

a) Before treat amounts taken at onset of study and considered baseline. ${ }^{\mathrm{b})}$ Six months from the start of the study. ${ }^{\mathrm{C})}$ Twelve months from the start of the study.

${ }^{*} \mathrm{P}<0.05 .{ }^{* *} \mathrm{P}<0.01$.

Table 2. Results of clinical observations (data OABq short; voiding diaries; $n=229$ )

\begin{tabular}{|c|c|c|c|c|c|c|c|c|c|c|c|c|}
\hline \multirow[b]{2}{*}{ Group } & \multicolumn{3}{|c|}{ Incontinence events/day } & \multicolumn{3}{|c|}{ Urgency episodes/day } & \multicolumn{3}{|c|}{ No. of urination/day } & \multicolumn{3}{|c|}{ Volume voided/once $(\mathrm{mL})$} \\
\hline & $\begin{array}{l}\text { Before } \\
\text { treat }^{\text {a) }}\end{array}$ & $\begin{array}{l}\text { After } \\
\text { treat }^{\text {b) }}\end{array}$ & $\begin{array}{l}\text { After } \\
\text { treat }^{\mathrm{c}}\end{array}$ & $\begin{array}{l}\text { Before } \\
\text { treat }^{\text {a) }}\end{array}$ & $\begin{array}{l}\text { After } \\
\text { treat }^{\text {b) }}\end{array}$ & $\begin{array}{l}\text { After } \\
\text { treat }^{\left({ }^{\prime}\right.}\end{array}$ & $\begin{array}{l}\text { Before } \\
\text { treat }^{\text {a) }}\end{array}$ & $\begin{array}{l}\text { After } \\
\text { treat }^{\text {b) }}\end{array}$ & $\begin{array}{l}\text { After } \\
\text { treat }{ }^{()}\end{array}$ & $\begin{array}{l}\text { Before } \\
\text { treat }^{\text {a) }}\end{array}$ & $\begin{array}{l}\text { After } \\
\text { treat }^{\text {b) }}\end{array}$ & $\begin{array}{l}\text { After } \\
\text { treat }^{c)}\end{array}$ \\
\hline 9) & 4.9 & * & $(0.9)^{*}$ & $4.6(0.9)$ & $1.1(1.0)^{*}$ & * & ) & * & * & 5) & $3)^{*}$ & 1 \\
\hline$B(n=51)$ & $5.3(1.6)$ & $2.2(0.9)^{*}$ & $3.7(1.3)$ & (2.1) & $0.9(0.7)^{*}$ & 4.5 & $8.0(2.9)$ & $4.8(1.2)$ & $5.8(3,4)$ & $101.9(14.3)$ & $161.8(19.4)^{*}$ & $114.5(9.3)$ \\
\hline (III) & (2.0) & (0.0) & (1.5) & $0.0(0.1)$ & $1.6(1.2)^{*}$ & $4.9(1.7)$ & $7.4(1.4)$ & $4.5(1.3)^{*}$ & $4.9(2.8)$ & $72.9(8.9)$ & $146.0(14.9)^{*}$ & $94.2(14.9)$ \\
\hline $\mathrm{D}(\mathrm{n}=56)$ & $5.1(2.1)$ & $2.7(1.1)$ & $4.8(2.4)$ & $5.6(1.2)$ & $4.6(2.5)$ & $4.7(3.1)$ & $7.6(1.8)$ & $7.1(3.1)$ & $6.9(1.9)$ & $93.8(14.8)$ & $111.7(23.7)$ & $81.4(9.3)$ \\
\hline
\end{tabular}

Values are presented as mean ( \pm standard deviation).

$\mathrm{OABq}$, overactive bladder questionnaire.

${ }^{a)}$ Before treat amounts taken at onset of study and considered baseline. ${ }^{\text {b) }}$ Six months from the start of the study. ${ }^{\mathrm{C})}$ Twelve months from the start of the study.

${ }^{\star} \mathrm{P}<0.05$. ${ }^{*} \mathrm{P}<0.01$.

months, then continued to decrease to 1.1 (standard deviation [SD], 0.7; P < 0.01) after 6 months and remained consistently low during year 1 at $1.5(\mathrm{SD}, 0.9 ; \mathrm{P}<0.05)$. The mean urinary urgency index in this subgroup decreased significantly by month 6 and remained low until month 12 after the start of the examination (4.6 [SD, 0.9] $\rightarrow 1.1[\mathrm{SD}, 1.0] \rightarrow 2.1[\mathrm{SD}, 1.4] ; \mathrm{P}<0.05)$. The median number of urinations per day also remained consistent- ly low within the stated control period $(7.2[\mathrm{SD}, 1.3] \rightarrow 4.1[\mathrm{SD}$, $0.9] \rightarrow 3.8$ [SD, 1.3]; $\mathrm{P}<0.05)$. The mean urine volume, which was initially $89.2(\mathrm{SD}, 8.5) \mathrm{mL}$, was $149.9(\mathrm{SD}, 15.3) \mathrm{mL}$ at month 6, and 139.8 (SD, 12.8) $\mathrm{mL}$ at the end of the observation period $(\mathrm{P}<0.05)$. Furthermore, we noted a high correlation between the urodynamic and clinical indices $(0.6 ; \mathrm{P}<0.05)$ when samples of number of events per day and reflex volume were com- 


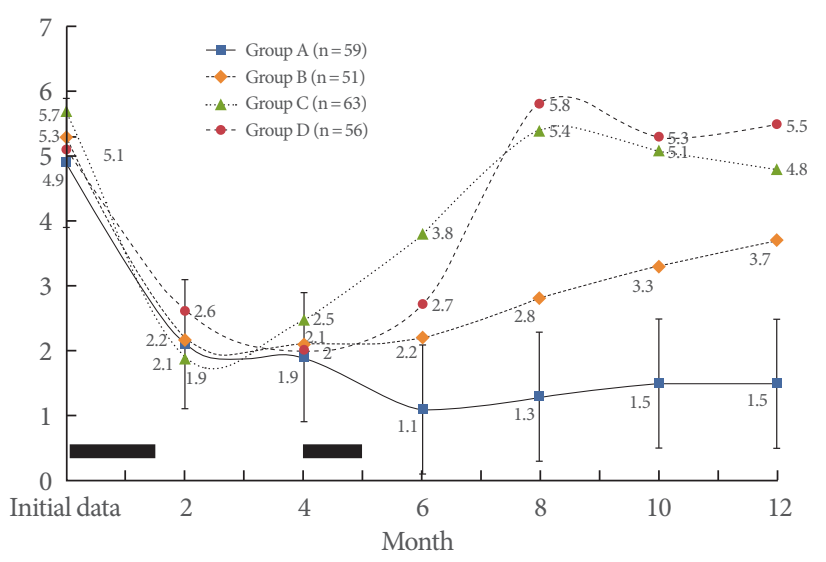

Fig. 2. The frequency of episodes of incontinence per day in elderly women with overactive bladder $(n=229)$. Horizontal lines indicate time of the basic and supporting courses of treatment.

pared.

The reflex volume was significantly different from the initial findings (145.8 [SD, 37.6] $\mathrm{mL}$ vs. 289.3 [SD, 63.7] $\mathrm{mL} ; \mathrm{P}<0.01)$ in the first follow-up study and (145.8 [SD, 37.6] $\mathrm{mL}$ vs. 257.5 [SD , 28.9] $\mathrm{mL} ; \mathrm{P}<0.01)$ in the final follow-up study. A significant increase in the bladder capacity was noted in both followup studies: 313.7 (SD, 47.1) mL, $\mathrm{P}<0.01,279.9$ (SD, 33.8) mL, $\mathrm{P}<0.05$; initial level 180.1 (SD, 31.0) $\mathrm{mL}$. Detrusor compliance increased by one-third at month 6 of the study and remained consistently high at the end of the study (from 20.2 [SD, 2.5] to 28.8 [SD, 4.7] to 32.8 [SD, 6.0] mL/cm $\mathrm{H}_{2} \mathrm{O} ; \mathrm{P}<0.05$ in both studies).

In groups $B$ and $C$, satisfactory results on the frequency of IE were observed after primary and maintenance treatment (month 4: 2.1 [0.8] for group B and 2.5 [0.5] for group C; month 6: 2.2 [0.9] for group B and 3.8 [0.8] for group C, under high correlation with urodynamic indications), but by month 8 the number of IE returned to the initial number in group C (5.4 [SD, 1.2]) and significantly increased in group $\mathrm{B}(2.8[\mathrm{SD}, 0.9], \mathrm{P} \geq 0.05)$.

The mean urinary urgency index in subgroup $\mathrm{B}$ was significantly lower than the initial index by month 6 , but returned to the initial index by the end of the examination $(5.1[\mathrm{SD}, 2.1] \rightarrow$ $0.9[\mathrm{SD}, 0.7] \rightarrow 4.5[\mathrm{SD}, 2.0])$. The mean urine volume per day changed throughout the year with the same pattern: 101.9 (SD, $14.3) \rightarrow 161.8$ (SD, 19.4) $\rightarrow 114.5$ (SD, 9.3). Although the median number of urinations per day in this group demonstrated a downward trend, it did not differ significantly from the initial pattern during the examination. The pattern of clinical indices in group $\mathrm{C}$ was close to that of group B, but excluding the fre- quency of urinations per day by month 6 of the observations, this index was significantly different from the initial one.

The final result for the frequency of IE in these groups was also unsatisfactory. In group B, the number of IE was 3.7 (SD, 1.3), and the differences from the initial level were statistically insignificant, but positive changes for reflex volume and detrusor compliance remained different from the initial findings (initial vs. first indicator, 136.1 [SD, 37.7] $\mathrm{mL}$ vs. 210.9 [SD, 28.7] $\mathrm{mL}$; initial vs. second indicator, 17.5 [SD, 3.3$] \mathrm{mL} / \mathrm{cm} \mathrm{H}_{2} \mathrm{O}$ vs. 30.9 [SD, 4.9] $\mathrm{mL} / \mathrm{cm} \mathrm{H}_{2} \mathrm{O}$ ). In group $\mathrm{C}$, the urodynamic indicators at the end of the study were significantly comparable to the initial indicators.

In group $\mathrm{D}$, in which patients received the placebo, the number of IE returned to the initial level by follow-up month 8 , and the final urodynamic indicators did not differ from the initial ones.

During the yearly follow-up study, two patients died of acute heart failure after active therapy. Nineteen patients $(8.3 \%)$ stopped treatment and examinations because of the development of sideeffects such as intolerable dry mouth (7), flatulence (1), nausea, vomiting (1) in 9 cases, soon after the start of the study because the patients did not experience a rapid positive effect in 3 cases, and owing to treatment-unrelated circumstances in 2 cases. Therefore, in the final stage (1 year after the beginning of the study), a urodynamic examination and analysis of diary records were performed for 203 patients (88.6\%).

\section{DISCUSSION}

Nowadays, OAB symptoms are effectively managed with antimuscarinic agents, but the long-term maintenance of stable results, especially in elderly patients, remains controversial [30-32]. We conducted a comparative analysis of several maintenance therapies in elderly women with $\mathrm{OAB}$, by examination of the long-term results.

A short treatment cycle with two high-dosage antimuscarinics of different generations, conducted 2.5 months after the main cycle, allowed the long-term maintenance of the initial clinical and urodynamic results. A comparative analysis of the pattern of clinical and urodynamic indices for the condition of the lower urinary tract demonstrated high and medium positive correlation in most cases. In particular, a change in the maximal bladder capacity correlates with clinical indices of daily mean urination frequency (direct correlation, $\mathrm{r}=0.65, \mathrm{P} \leq 0.05$ ), urinary urgency (inverse correlation, $\mathrm{r}=-0.55, \mathrm{P} \leq 0.05$ ), frequency of 
IE $(r=-0.67, P \leq 0.05)$, and mean urine volume per day $(r=0.71$, $\mathrm{P} \leq 0.05)$. In group $\mathrm{A}, 77.9 \%$ of patients stated a significant improvement in the quality of life due to regression of OAB symptoms by the end of follow-up period, and $10.2 \%$ described the change in their condition as "moderately improved."

Electrical stimulation of the urinary bladder as maintenance therapy proved to be less effective. Although the frequency of IE during the follow-up study remained lower than the initial finding of 3.7 (1.3), it was not significantly different. Urodynamic indices also worsened, although the reflex volume and detrusor compliance for the entire group was significantly different from the initial findings. The percentage of patients who rated their quality of life as "significantly improved" due to regression of OAB symptoms in the group was $41.2 \%$.

In groups $\mathrm{C}$ and $\mathrm{D}$, a study of the urodynamics and symptoms of $\mathrm{OAB}$ demonstrated a deterioration in the results by months $6-8$, which led us to conclude that laser puncture is an inefficient maintenance therapy in elderly women with $\mathrm{OAB}$.

A comparison of the pattern of clinical and urodynamic indices for the condition of the lower urinary tract demonstrated a correlation between the most similar parameters in both groups. For example, the frequency of urination per day, IE, urinary urgency, and the mean urine volume changed almost simultaneously $(r=0.51-0.69 ; \mathrm{P} \leq 0.05)$. In our opinion, it significantly proves that despite the various mechanisms of action of the laser puncture and the psychogenic influence of placebo on the condition of the lower urinary tract, the effect in both groups was poor. The percentage of patients who cited an improvement in the quality of life at the end of the follow-up period was $17.4 \%$ and 3.6\% for groups $\mathrm{C}$ and $\mathrm{D}$, respectively.

The results observed in group A may be related to the efficiency of the synergistic activation of $\mathrm{M}_{2}$ and $\mathrm{M}_{3}$ receptors, which are well preserved in the bladder of elderly women [4,33], with high stabile functional activity after maintenance therapy. The synergistic activation of different receptors and, probably, the action of $\mathrm{M}_{2}$ and $\mathrm{M}_{3}$ receptors at different structural levels of the detrusor when trospium and solifenacin are administered twice in elderly women, might be a rational explanation for the positive results obtained for the recommended therapy cycle $[33,34]$. An attempt to influence the microcirculation in the detrusor using electrical stimulation is not sufficiently satisfactory owing to the short-term benefit and, probably, the absence of its specific influence on groups of receptors, which are mainly preserved in the bladder of elderly women.

In conclusion, this study confirmed our earlier results con- cerning the high effectiveness and safety of high-dosage trospium and solifenacin for the treatment of OAB in elderly women, and proved that a repeated cycle of such treatment for 2 months significantly decreases the probability of recurrence of $\mathrm{OAB}$ in elderly women during 1 year, with an acceptable level of side effects. At the same time, it was determined that the application of methods such as electrical stimulation and laser puncture does not ensure maintenance of the positive effect of primary pharmaceutical therapy over the course of 1 year.

Further studies are needed to determine the necessary conditions for repeated cycles of the maintenance pharmaceutical treatment of $\mathrm{OAB}$ in elderly patients for $>1$ year.

\section{CONFLICT OF INTEREST}

No potential conflict of interest relevant to this article was reported.

\section{REFERENCES}

1. de Ridder D, Roumeguere T, Kaufman L. Overactive bladder symptoms, stress urinary incontinence and associated bother in women aged 40 and above; a Belgian epidemiological survey. Int J Clin Pract 2013;67:198-204.

2. Sexton CC, Coyne KS, Thompson C, Bavendam T, Chen CI, Markland A. Prevalence and effect on health-related quality of life of overactive bladder in older americans: results from the epidemiology of lower urinary tract symptoms study. J Am Geriatr Soc 2011; 59:1465-70.

3. Lee YS, Lee KS, Jung JH, Han DH, Oh SJ, Seo JT, et al. Prevalence of overactive bladder, urinary incontinence, and lower urinary tract symptoms: results of Korean EPIC study. World J Urol 2011;29: 185-90.

4. Andersson KE. Muscarinic acetylcholine receptors in the urinary tract. Handb Exp Pharmacol 2011;(202):319-44.

5. Harris C, Smith PP. Overactive bladder in the older woman. Clin Geriatr 2011;18;41-7.

6. Brostrom S, Hallas J. Persistence of antimuscarinic drug use. Eur J Clin Pharmacol 2009;65:309-14.

7. Wyndaele JJ. Conservative treatment of patients with neurogenic bladder. Eur Urol Suppl 2008;7:557-65.

8. Johnson TM 2nd, Burgio KL, Redden DT, Wright KC, Goode PS. Effects of behavioral and drug therapy on nocturia in older incontinent women. J Am Geriatr Soc 2005;53:846-50.

9. Kosilov K, Loparev S, Ivanovskaya M, Kosilova L. Management of 
overactive bladder $(\mathrm{OAB})$ in elderly men and women with combined, high-dosage antimuscarinics without increased side effects. UroToday Int J 2013;6:art 47.

10. Amend B, Hennenlotter J, Schafer T, Horstmann M, Stenzl A, Sievert KD. Effective treatment of neurogenic detrusor dysfunction by combined high-dosed antimuscarinics without increased sideeffects. Eur Urol 2008;53:1021-8.

11. Horstmann M, Schaefer T, Aguilar Y, Stenzl A, Sievert KD. Neurogenic bladder treatment by doubling the recommended antimuscarinic dosage. Neurourol Urodyn 2006;25:441-5.

12. Ruby CM, Hanlon JT, Boudreau RM, Newman AB, Simonsick EM, Shorr RI, et al. The effect of medication use on urinary incontinence in community-dwelling elderly women. J Am Geriatr Soc 2010;58: 1715-20.

13. Chapple C. New once-daily formulation for trospium in overactive bladder. Int J Clin Pract 2010;64:1535-40.

14. Wyndaele JJ, Goldfischer ER, Morrow JD, Gong J, Tseng LJ, Guan Z, et al. Effects of flexible-dose fesoterodine on overactive bladder symptoms and treatment satisfaction: an open-label study. Int J Clin Pract 2009;63:560-7.

15. Brubaker L. Electrical stimulation in overactive bladder. Urology 2000;55(5A Suppl):17-23.

16. Slovak M, Barker AT, Chapple CR. The assessment of a novel electrical stimulation waveform recently introduced for the treatment of overactive bladder. Physiol Meas 2013;34:479-86.

17. Lewey J, Lilas L. Electrical stimulation of the overactive bladder. Prof Nurse 1999;15:211-4.

18. Ozdedeli S, Karapolat H, Akkoc Y. Comparison of intravaginal electrical stimulation and trospium hydrochloride in women with overactive bladder syndrome: a randomized controlled study. Clin Rehabil 2010;24:342-51.

19. Leong FC, McLennan MT. Neuromodulation for the treatment of urinary incontinence. Mo Med 2007;104:435-9.

20. Bschleipfer T, Ludecke G, Durschnabel M, Wagenlehner FM, Weidner W, Pilatz A. Auricular acupuncture in patients with detrusor overactivity: a pilot study. Urologe A 2013 Apr 20 [Epub]. http:// dx.doi.org/10.1007/s00120-013-3189-2.

21. Emmons SL, Otto L. Acupuncture for overactive bladder: a randomized controlled trial. Obstet Gynecol 2005;106:138-43.
22. Kitakoji H, Terasaki T, Honjo H, Odahara Y, Ukimura O, Kojima M, et al. Effect of acupuncture on the overactive bladder. Nihon Hinyokika Gakkai Zasshi 1995;86:1514-9.

23. Tian FS, Zhang HR, Li WD, Qiao P, Duan HB, Jia CX. Study on acupuncture treatment of diabetic neurogenic bladder. Zhongguo Zhen Jiu 2007;27:485-7.

24. Parsons M, Amundsen CL, Cardozo L, Vella M, Webster GD, Coats AC, et al. Bladder diary patterns in detrusor overactivity and urodynamic stress incontinence. Neurourol Urodyn 2007;26:800-6.

25. Amundsen CL, Parsons M, Cardozo L, Vella M, Webster GD, Coats AC. Bladder diary volume per void measurements in detrusor overactivity. J Urol 2006;176(6 Pt 1):2530-4.

26. Winters JC, Dmochowski RR, Goldman HB, Herndon CD, Kobashi KC, Kraus SR, et al. Urodynamic studies in adults: AUA/ SUFU guideline. J Urol 2012;188(6 Suppl):2464-72.

27. Woodford H, George J. NICE guidelines on urinary incontinence in women. Age Ageing 2007;36:349-50.

28. Singh G, Lucas M, Dolan L, Knight S, Ramage C, Hobson PT, et al. Minimum standards for urodynamic practice in the UK. Neurourol Urodyn 2010;29:1365-72.

29. Schafer W, Abrams P, Liao L, Mattiasson A, Pesce F, Spangberg A, et al. Good urodynamic practices: uroflowmetry, filling cystometry, and pressure-flow studies. Neurourol Urodyn 2002;21:261-74.

30. Chancellor MB, Anderson RU, Boone TB. Pharmacotherapy for neurogenic detrusor overactivity. Am J Phys Med Rehabil 2006;85: $536-45$.

31. Ulahannan D, Wagg A. The safety and efficacy of tolterodine extended release in the treatment of overactive bladder in the elderly. Clin Interv Aging 2009;4:191-6.

32. Chancellor MB, Zinner N, Whitmore K, Kobashi K, Snyder JA, Siami P, et al. Efficacy of solifenacin in patients previously treated with tolterodine extended release $4 \mathrm{mg}$ : results of a 12-week, multicenter, open-label, flexible-dose study. Clin Ther 2008;30:1766-81.

33. Kanai AJ. Afferent mechanism in the urinary tract. Handb Exp Pharmacol 2011;(202):171-205.

34. Igawa Y, Aizawa N, Homma Y. Beta3-adrenoceptor agonists: possible role in the treatment of overactive bladder. Korean J Urol 2010; 51:811-8. 